\title{
Evaluation Of Land Carrying Capacity In Tsunami Affected Areas Of Aceh Besar Regency
}

\author{
Widodo \\ Agribusiness Department \\ Universitas Muhammadiyah Yogyakarta \\ Yogyakarta, Indonesia \\ widodo@umy.ac.id
}

\author{
Aris Slamet Widodo \\ Agribusiness Department \\ Universitas Muhammadiyah Yogyakarta \\ Yogyakarta, Indonesia \\ armando1215sw@gmail.com
}

\author{
Nanda Chintia Melrhoza \\ Agribusiness Department \\ Universitas Muhammadiyah Yogyakarta \\ Yogyakarta, Indonesia \\ nandamelrozha@gmail.com
}

\begin{abstract}
Aceh tsunami disaster in 2004 caused damage to agricultural land in Aceh Besar Regency. Meanwhile the postdisaster development has caused migration of people to the regency, causing a greater pressure on agricultural land. The study aimed to evaluate the land carrying capacity in tsunamiaffected areas in Aceh Besar Regency in 2005-2016. Data including rice production, harvested area, and population size in 2005-2016 were obtained from the Central Bureau of Statistics of Aceh Besar Regency. The level of land carrying capacity was approached by the ratio of per capita rice harvested area to the land area to achieve self-sufficiency. The results showed that one sub-district which were characterized as agricultural areas achieved a recovery on class $I$ of land carrying capacity in 2009 to 2012 . A total of two sub-districts are included to class II of land carrying capacity and four subdistricts are included to class III of land carrying capacity. It can be concluded that the land carrying capacity in tsunami affected areas in Aceh Besar Regency experiences partial recovery, that is on agricultural areas.
\end{abstract}

Keywords-Aceh Besar Regency, land carrying capacity, optimum population

\section{INTRODUCTION}

There are changes in the agricultural land in Aceh Besar Regency due to tsunami disaster in Aceh. Based on data obtained from the Central Bureau of Statistics (BPS) of Aceh Besar Regency, the rice harvested area in 2003 was 40,623 hectares but decreased in 2005 to 32,370 hectares after the tsunami disaster. In addition, the rice production in Aceh Besar Regency in 2003 was 191,894 tons, which also decreased after the tsunami disaster to 153,446 tons in 2005. The damage on the field after the tsunami disaster in Aceh could be seen from the condition of grass and rice fields that were totally destroyed, causing the land to not be cultivable for a long time due to its too high salinity level. In addition to the damaged rice fields, thousands of the community's wells were also polluted. This condition had stagnated the development in agricultural sector, require serious activities for recovery. Earthquakes, saltwater (salinity) and thick sludge (sediment) make a serious agricultural land damage [1].

However, massive development in Aceh had attracted people to move into Aceh because they believed there were a lot of new promising jobs, so it triggered population growth. In 2005-2009, the population of Aceh Besar had reached 45,000. Unfortunately, the population growth of Aceh Besar caused both more pressure on agriculture landbecause land was converted into housing areas [2] and increase in food needs. If we let this situation occur, there will be a gap between food availability and the needs for food of the population. In the worst case, the region will not be able to meet the food needs of its population.

Some previous research has been done to evaluate the soil and water characteristics affected by the tsunami disaster in Lhoknga Sub-District of Aceh Besar Regency [3]. Other similar research has been done in Lhoong Sub-District [4], which was a follow-up of a previous study to evaluate the carrying capacity. Land carrying capacity is the population size in a region that can be sustained without causing degradation on land [5]. Some research on land carrying capacity have been conducted, such as in Madiun [6] and Lamongan [7]. This research aimed to evaluate the land carrying capacity in the sub-districts in Aceh Besar Regency that were affected by the tsunami and to know the maximum population size in each sub-district.

\section{METHODS}

The research was conducted in seven sub-districts in Aceh Besar Regency which were affected by the tsunami disaster. Aceh Besar Regency was the center of rice production in Aceh Province that had large rice fields. Meanwhile those seven sub-districts experienced the worst damage by the tsunami among other sub-districts in Aceh Besar Regency.

The data which were analyzed in this research were the population size, rice harvested area, rice field production, and minimum physical consumption in 2005-2016. All the data were taken from the Central Bureau of Statistics of Aceh Besar Regency.

The data analysis technique to determine the level of the carrying capacity of agriculture land was a mathematical formula based on Odum, Christeiler, Ebenzern Howard and Issard theory [8]:

$$
\alpha=\frac{X}{K}
$$

The notation of $\alpha$ is the level of land carrying capacity, $\mathrm{X}$ is harvested area of food crops, and $\mathrm{K}$ is the area of food crops on self-sufficiency of food. Land carrying capacity is categorized to class 1 if equal to more than 2.47 , meaning that a region is capable of meeting food self-sufficiency and capable of providing a decent life for its inhabitants. Land carrying capcaity is categorized to class 2 if it is within 12.47 , meaning that a region is capable of meeting food selfsufficiency but is not capable of providing a decent life for 
its inhabitants. Furthermore, if land carrying capacity is equal to or less than 1 , it means that a region is not food selfsufficient.

\section{RESULTS AND DISCUSSION}

The areas of Aceh Besar Regency which were affected by the tsunami disaster could be divided into three groups. The first area is characterized as agricultural area, including Lhoong and Lhoknga Sub-districts. The second area is characterized as fishery area, including Leupung, Peukan Bada, and Pulo Aceh Sub-districts. The third is characterized as urban area, including Mesjid Raya and Baitussalam Subdistricts.

\section{A. Sub-districts characterized as agricultural area}

Lhoong Sub-district and Lhoknga Sub-district are included as agricultural areas, because they have a quite large agricultural land. They have 1.122 hectares and 1.000 hectares of agricultural lands, respectively. Furthermore, the highest source of income of these subdistricts are food crops sector. Figure 1 shows the land carrying capacity of both of those sub-districts.

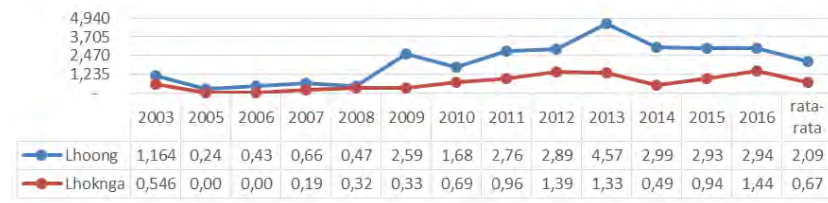

Figure 1. Land carrying capacity in Lhoong and Lhoknga Sub-districts

Based on the Figure 1, it can be concluded that Lhoong Subdistrict has a higher level of land carrying capacity than Lhoknga Sub-district. It can be seen in 2005 to the following years, Lhoong Subdistrict started its recovery period, indicated by an increase in the level of land carrying capacity from 0.24 in 2005 to 0.66 in 2007, meanwhile, the recovery period of Lhoknga Sub-district began in 2007 with a land carrying capacity of 0.19 .

It can be seen that in 2005 until 2007, Lhoong and Lhoknga Sub-districts were at class 3 in terms of their land carrying capacity, which means that these sub-districts were not food self-sufficient and not able to provide a decent life for the populations.

In 2009 Lhoong Sub-district had a quite significant increase in the level of land carrying capacity, i.e. 2.59. This means that Lhoong Subdistrict was food self-sufficient and able to provide a decent life for the population, while in 2009 the level of land carrying capacity in Lhoknga Sub-district was 0.33 . There was not a significant increase in the level of land carrying capacity in Lhoknga Sub-district, and this situation remained for the next 4 years. In 2011 until 2013, Lhoong Sub-district had a significant increase. The highest level of land carrying capacity that Lhoong Sub-district had occurred in 2013, i.e. 4.57. That means, Lhoong Sub-district was food self-sufficient and able to provide a decent life for the population. For Lhoknga Sub-district, a significant increase took place in 2012 with a land carrying capacity of 1.39. That means Lhoknga Sub-district was food self- sufficient but still not able to provide a decent life for the population. This condition remained until 2013.

In 2014, both of the two sub-districts had a decrease in land carrying capacity. But the most significant decrease took place in Lhoknga Subdistrict. In 2014 until 2015, the level of land carrying capacity in Lhoknga Sub-district was in class 3 . That means, the sub-district was neither food selfsufficient nor able to provide a decent life for the population. But in 2016, it increased again to 1.44. On the other hand, from 2014 until 2016, the land carrying capacity in Lhoong Sub-district was quite stable, i.e. in class 1 . This means that Lhoong Sub-district was food self-sufficient and also able to provide a decent life for the population.

Based on the Figure 1, we can conclude that the land carrying capacity in Lhoong Sub-district is much better than that in Lhoknga Subdistrict. Lhoong Subdistrict also tends to have a faster recovery period than Lhoknga Subdistrict. This is in line with some previous research [3], [4].

This research revealed that the land in Lhoong Subdistrict which had a high level of damage included in class $\mathrm{C}$ was the land with a damage level of around $35 \%$ and a total damaged land of 689 hectares. A medium level of damage included in class B was with a damage level of around $40 \%$ and a total damaged land of 788 hectares. Meanwhile, the low level of damage included in class A was with a damage level of around $25 \%$ and a total damaged land of 493 hectares [4]. A similar research showed that the land in Lhoknga Sub-district which had a high level of damage and included in class $\mathrm{C}$ was the land with a damage level of around $52 \%$, and a total damaged land of 624 hectares. The medium level of damage included in class B was with a damage level of around 8\%, and a total damaged land of 96 hectares. The low level of damage included in class A was with a damage level of around $40 \%$, and a total damaged land of 480 hectares [3]. So, we know that class B dominated the damaged land in Lhoong Sub-district, while in Lhoknga Sub-district class $\mathrm{C}$ was more dominant. Therefore, the recovery process in Lhoong Sub-district took shorter time compared to Lhoknga Sub-district because the level of damage in Lhoong was not as severe as in Lhoknga.

\section{B. Sub-districts characterized as fishery area}

Leupung, Peukan Bada, and Pulo Aceh Sub-districts are fisheries and agricultural areas, considering the fact that the main sources of income in those areas are food crops and fisheries sector. Moreover, the total raw land available in those areas are quite large, i.e. 570 hectares, 815 hectares and 313 hectares, respectively. Based on the chart above, it can be concluded that Peukan Bada Sub-district had a rapid increase in the land carrying capacity than the other subdistricts, evident from the increase in the land carrying capacity of that area in 2006 or 2 years after the tsunami disaster. On the other hand, Leupung and Pulo Aceh had a slow increase in the land carrying capacity, evident from the increase in the land carrying capacity in those sub-districts that took place in 2009 or 5 years after the tsunami disaster. In 2010, Leupung Sub-district had a significant increase in the land carrying capacity to 1.73 , that means, Leupung Subdistrict was food self-sufficient but still not able to provide a 
decent life for the population. On the other hand, Peukan Bada Sub-district and Pulo Aceh Sub-district did not have significant changes, but in 2016 Pulo Aceh Sub-district had an increase in the land carrying capacity to 1.62 . This means that Pulo Aceh Sub-district was food self-sufficient but still not able to provide a decent life for the population. Overall, the land carrying capacity in Peukan Bada and Pulo Aceh Sub-districts was in class III, meaning that those areas were neither food self-sufficient nor able to provide a decent life for the population.

Figure 2. Land carrying capacity in Leupung, Peukan Bada, and Pulo Aceh Sub-districts

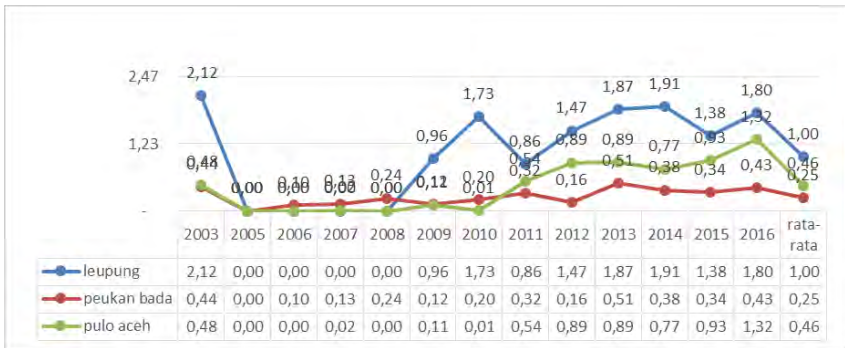

In terms of the recovery process, Peukan Bada had a faster recovery process than Leupung and Pulo Aceh Subdistricts. Although the land recovery process in Leupung Sub-district was slower, the increase in the land carrying capacity in Leupung was better every year compared to those in the other sub-districts.

\section{Sub-districts characterized as urban area}

Mesjid Raya and Baitussalam are included as Urban areas because both of those sub-districts are located near the city area although they are far from the capital of the regency. However, the distance between these two subdistricts and the capital of the province is quite close. The characteristics of these areas are there are no large rice fields due to agricultural land conversion that usually takes plce in those areas, and population size that keeps increasing, causing agricultural land to be converted into housing.

Figure 3. Land carrying capacity in Mesjid Raya and Baitussalam Sub-districts

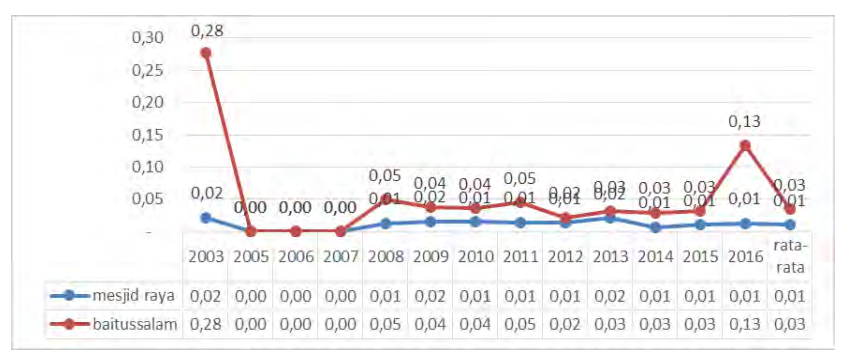

Based on the chart above, it can be concluded that there are no significant changes in the land carrying capacity. Overall, both sub-districts were included to class III, meaning that those areas were neither food self-sufficient nor able to provide a decent life for the population. In Mesjid Raya Sub-district, this occurred because of several factors. In addition to the disaster that caused the rice fields to be not cultivable for a long time, another factor is because this area was quite close to the capital of the province, making it targeted to be a residential area. The higher population growth, the higher convertion of agricultural land into a residential area. On the other hand, the higher the population growth, the higher the needs for agricultural land to meet the food needs of the population. Moreover, Mesjid Raya Subdistrict is located near coastal area, causing it to not have large rice fields. In fact, the main source of income in that subdistrict was fisheries sector. There were eight villages having fisheries sector, but only one village having food crop sector.

Similarly, the low level of land carrying capacity in Baitussalam Sub-district occurred because of several factors. In addition to the tsunami disaster and its location being close to the urban area, another factor is because the district is located near the coastal area, causing it to not have large rice fields. The main source of income in that subdistrict was also fisheries sectors. There were three villages having fisheries sector, but only one village having food crop sector.

In terms of the recovery process, it could be concluded that these sub-districts started their recovery progress in 2008 or 4 years after the tsunami disaster.

\section{Maximum Population Size}

It is known that the maximum population sizes in each sub-district varied. It depends on the original population sizes in the sub-districts and also the levels of land carrying capacity. There are two classifications of sub-districts, namely those whose maximum population size exceeds the original population, and those whose maximum population size is less than the original population.

Table 1. Maximum population size

\begin{tabular}{lrcr}
\hline Sub-district & $\begin{array}{c}\text { Population size } \\
\text { in 2016 }\end{array}$ & $\begin{array}{c}\text { Carrying } \\
\text { capacity }\end{array}$ & $\begin{array}{r}\text { Maximum } \\
\text { population }\end{array}$ \\
\hline Lhoong & 10,354 & 2.94 & 30,408 \\
Lhoknga & 16,904 & 1.44 & 24,308 \\
Leupung & 2,919 & 1.80 & 5,258 \\
Mesjid Raya & 23,785 & 0.01 & 308 \\
Baitussalam & 18,878 & 0.13 & 2,517 \\
Peukan & 17,792 & 0.43 & 7,662 \\
Bada & & & \\
Pulo Aceh & 4,315 & 1.32 & 5,679 \\
\hline
\end{tabular}

There are 4 sub-districts whose population sizes exceed the original population. They are Lhoong, Lhoknga, Leupung and Pulo Aceh Subdistricts. There are 3 subdistricts whose population sizes are less than the original population, namely Mesjid Raya, Baitussalam and Peukan Bada Sub-districts. There are several factors causing the difference in the maximum population sizes, namelythe level of rice production, harvested area, and the land carrying capacity in each sub-district.

There is a difference in the levels of recovery of the land carrying capacity in the tsunami-stricken areas in Aceh Besar Regency, characterized by agricultural, fisheries and urban areas. The land carrying capacity in agricultural areas (Lhoong and Lhoknga Subdistricts) experiences the fastest recovery compared to the other five areas in coastal and urban areas. The development of the Province of Nangroe 
Aceh Darussalam after the tsunami is directed based on zoning of land use suitability for agriculture and other sectors. Thus the economic development priorities are adjusted to the local economy such as agriculture, fisheries, plantations, etc. [9]. As a consequence, agricultural development is put in a low priority in some nonagricultural areas so that these areas are less able to meet their food needs. However, these food needs can be met from the surrounding areas that have surplus in production, as occurred in Lamongan Regency [7].

\section{CONCLUSION}

There is one sub-district that is included to class I, that mean this sub-districts are able to do self-sufficiency of food and also able to provide a decent life for the population in 2016. There are two sub-districts which are included to class II of land carrying capacity, i.e. Lhoknga and Leupung Subdistrict, meaning that these subdistrict are food selfsufficient but still unable to provide a decent life for the population. There are four sub-districts included to class III of land carrying capacity, namely Masjid Raya, Baitussalam, Peukan Bada and Pulo Aceh Subdistricts, meaning that these sub-districts are neither food selfsufficient nor able to provide a decent life for the population.

In terms of the maximum population size, it is known that there are four sub-districts whose maximum population sizes exceed the original population of the areas, namely Lhoong, Lhoknga, Leupung, and Pulo Aceh Sub-districts, and there are three sub-districts with maximum population sizes less than the original population, namely Mesjid Raya, Baitussalam, and Peukan Bada.

\section{REFERENCES}

[1] Indonesian Agency for Agricultural Research and Development, "Berita," Dampak Tsunami Terhadap Sektor Pertanian, 2005. [Online]. Available: http://www.litbang.pertanian.go.id/berita/one/192/. [Accessed: 21Apr-2018].

[2] J. Sepriana, A. Karim, and I. Indra, "Dampak Pengembangan Bandara Sultan Iskandar Muda Terahadap Alih Fungsi Lahan Sawah Dan Nilai Lant Rent," J. Manaj. Sumberd. Lahan, vol. 3, no. 2, pp. 442-451, 2014.

[3] S. Syakur, H. Basri, S. Sufardi, and M. Hatta, "Sifat Tanah Dan Air Yang Terpengaruh Tsunami Di Kecamatan Lhoknga Kabupaten Aceh Besar," J. Floratek, vol. 7, pp. 1-12, 2012.

[4] H. Basri, S. Syakur, and A. Rusdi, "Sifat-Sifat Tanah Dan Air Yang Terpengaruh Tsunami Di Kecamatan Lhoong Kabupaten Aceh Besar," J. Floratek, vol. 6, pp. 144-157, 2011.

[5] B. Ma, "Literature review on land carrying capacity of the coordinated development of population, resources, environment and economy," in 2nd International Conference on Materials Science, Resource and Environmental Engineering (MSREE 2017), 2017, pp. 40106-1-7.

[6] R. D. S. Kuncoro, "Analisis Daya Dukung Dan Kebutuhan Lahan Pertanian Di Kabupaten Madiun Tahun 2032," in Prosiding Seminar Nasional PENGELOLAAN SUMBERDAYA WILAYAH BERKELANJUTAN, 2017, pp. 370-380.

[7] I. A. Syaiful Huda and D. S. Suwargany, Melly Heidy Anjarika, "Analisis Daya Dukung Dan Kebutuhan Lahan Pertanian Di Kabupaten Lamongan Tahun 2035," in Prosiding Seminar NASIONAL PENGELOLAAN SUMBERDAYA WILAYAH BERKELANJUTAN, 2017, pp. 396-405.
[8] Suhardjo and Tukiran, Studi Literatur Konsep yang Sudah Ada Mengenai Daya Tampung Wilayah. Jakarta: Kantor Menteri Negara Kependudukan dan Lingkungan Hidup, 1990.

[9] Sukiman, "Acuan Pembangunan Aceh Pasca Tsunami Ke Arah Pembangunan Berasaskan Islam," MIQOT, vol. 34, no. 2, pp. 303 321,2010 